\title{
THE (IR)RELEVANCY OF THE ACADEMIC STUDY OF THE BIBLE
}

J Eugene Botha

Unisa

\section{Abstract}

In this paper it is argued that the academic study of the Bible in the South African context finds itself in a very serious situation. It is in danger of going under and vanishing from the university scene forever, and even more serious, that its disappearance into the void would hardly raise an eyebrow of concern: not from the academic world nor from various Christian faith communities which, ironically build their faith on the study of the Bible. This paper is an exploration into some of the reasons for the relevancy of the academic study of the Bible in South Africa today. A few observations on possibilities to redeem the situation are also made.

\section{Introduction}

No discourse takes place in a vacuum, and this paper is no exception. Perhaps more than ever before we are now conscious of the enormous influence our context has on our perceptions and the way in which we conduct our business as academics. The days of the ivory tower academics are long gone and it is with a bang that many of us has woken up to a new context in a new society under a new constitution. Our context today, is a pluralistic, supposedly non-sexist and non-racist context where transformation and restructuring are the buzz words. However, I would further like to locate this paper not only in the context of a changed society, but also in the context of Unisa, as a member of the Departments of Old and New Testaments' programme of presenting subjects called Biblical Studies and Old and New Testament. For many years, these two Departments accounted for the majority of students at the Faculty of Theology and Religious Studies, mainly through the Biblical Studies courses presented to Arts students who took Biblical Studies as a subject because it was also an accepted 'examination' subject. We literally had thousands of students and at many a meeting many a joke was cracked at the expense of other Departments at the Faculty of Theology \& Religious Studies to the effect that Old and New Testament were carrying the other departments or that the other theological disciplines were being subsidised by Biblical Studies.

These days are also now long gone! The stream of students enrolling for Biblical Studies has suddenly, over the last year or two dwindled to a mere trickle, and suddenly both departments of Old and New Testament find themselves in a threatened position: threatened in terms of relevance and of existence. However, to be fair to the beleaguered colleagues at Unisa, what is happening at Unisa is also happening all over the country: at many institutions and at many colleges Biblical Studies Departments and even Religious Studies Departments are loosing students and are being phased out. It is happening all around: University of Venda, University of the North, Rhodes University, University of the Witwatersrand and so on.

The question immediately arises: why? Why is this happening? Certainly the change in political climate and the changes to a secular state are reason enough, and it is not worthwhile for students to take something like Biblical Studies or Religious Studies as a subject anymore. But the deeper question still remains: did we only have students in the past 
because of ulterior considerations like salary increases and the perception that Biblical Studies at University is a 'soft option'? If we all lose students because no external 'coercion' or 'financial reward' exist any longer, then the ugly, and long ignored question of relevance raises its head: has the academic study of the Bible become so irrelevant that of itself it can no longer generate interest enough to keep itself going at Universities amongst the other disciplines? It indeed seems to be the case. This paper is primarily an exploration of the reasons for this irrelevancy and it also takes a look at the relevance of maintaining the academic study of the Bible at universities in a new South Africa.

\section{The history of study of the Bible in an academic (read: non-church) setting}

I wish to emphasise here that what I am talking about in this paper is the academic study of the Bible at non-denominationally regulated institutions like Universities and Colleges. In South Africa we have a long tradition of having a subject called 'Biblical Studies' which was presented at Universities, as part of the arts curriculum, and which was (supposedly) not linked to any specific church, denomination or faith community. However, much of what I am about to say also holds true for the study of the Bible at denominationally linked institutions.

Bassett (1998), whilst building on Farley's 1983 work Theologia: The Fragmentation and Unity of Theological Education points out that initially, Theology, and with it the study of the Bible, was conceptualised by the second and third century Christian thinkers as a habitus ${ }^{1}$, and that to this sense Clement also added the element of paideia, (a Greek concept which refers to character development) to it, with the result that Theology soon becomes a quest for understanding everything, including nature and humanity, in terms of revelation, grace and redemption, with the added moral education and character formation in the context of the believing body of Christ of all Christians, laity and ordained together (Bassett 1988:9) $)^{2}$. This means that theology or theologia, was the sine qua non of all understanding, and that the point of departure of any 'investigative process' (to use an anachronism), was the inherent notions of theologia as grace, etc. However, this idea of what theology is, though very influential, underwent radically changes with the advent of the medieval university. Farley (1983:33) indicates that the notion of theology as an academic discipline, or as a cognitive enterprise, did not really exist prior to the Middle Ages. There was only this one sense of theology as 'salvific oriented knowledge' (Farley 1983:33).

Farley (1983:34ff) indicates that gradually the notion of theologia as a 'habitus' with a character formation component, was changed into a full blown academic discipline from about the twelfth. century onwards. Theologia now also becomes a scientia, 'in the distinctive scholastic sense of a method of demonstrating conclusions' (Farley 1983:34). Whereas theology used to be the starting point of investigation, through which all investigation proceeded, and which proceeded along the lines of learning, teaching and exposition of doctrine, especially under scholars such as Aquinas and the schoolmen, theology gradually became a discipline in the Aristotelian sense of a demonstrative undertaking. The renaissance of Aristotle and its influence on Peter Lombard, Abelard, Hugh of St. Victor and Gilbert of Porrée forever changed theology into a science, albeit in a scholastic sense. Farley (1983:37-38) furthermore indicates that "the coming of Aristotle to

1. Bassett (1998:9) mentions that 'habitus' in this regard refers to a 'proactive and pervasive disposition to know and understand God and the things of God in terms of revelation and redemption', see also Farley (1983:31).

2. See Clement Stromata V.3,12-13, VII.9 passim. 
Christian learning may have been the decisive catalyst for the precipitation of the new theological science, but it was not the only stimulus' and continues to demonstrate that the influence of classical dialectic with its distinction between commentary-exposition (lectio) and rational enquiry, enabled theology to take up a legitimate place at the table of other sciences. Bassett (1998:10) remarks that in the medieval universities theologia actually became the aim or end goal of all sciences, but nevertheless a scientific undertaking. Theology and the academic study of the Bible thus became firmly entrenched as academic disciplines in universities, and co-existed with Faculties of Law and Medicine. Farley (1983:38) also remarks that it is significant that theology as scientia developed in universities and 'not institutions presided over by bishops or abbots created a new distance between theology and the church'. This distance was to continue and grow over the centuries. However, the notion of theology as habitus or as disposition or as wisdom continued its existence, especially in church settings. This stage in the development of theology as scholastic discipline, Farley (1983:39) roughly places in time between the twelfth and seventeenth centuries.

He then further continues to argue that two movements provided the impetus for a new evaluation of the medieval scholastic discipline of theologia. The first of the two movements was the Enlightenment which builds on the revival of classical learning and which had its setting in the modern university. The second of the movements Farley (1983:39) identifies is continental pietism, which builds on traditions from Catholic Mysticism, the Reformation and English puritanism, amongst others, and while it was initially also located in universities, it soon moved from there and became located in the denominational seminary. Both of these movements constitute a criticism of the scholastic theologies preceding it, but with very different outcomes.

The location of theology in the modern university ${ }^{3}$ had the result that theology could rid itself once and for all of the fetters of church, which still to a large extent dominated preenlightenment theologies through its articuli fidei (see Farley 1983:41). With the Enlightenment came the ideals of autonomous cognitive science, scholarship, method, evidence, criticism and the like, and also a differentiation of the one theologia into various sub-disciplines. Farley (1983: 41-42) further argues:

With this came historical sense and historical-critical methods of interpretation. And these things in turn revolutionized the human and social sciences into disciplines (sciences) in a new sense... one result of this revolution was that new sciences, new bodies of data and new methods were available to theology: philology, history, hermeneutics. In the mid-eighteenth century Ernesti and Semler appropriated these for Biblical interpretation. And once this happened, it became apparent that the Bible itself could be the object of a 'science', a collection to which critical, autonomous methods of interpretation could be applied. It was only a short step to realize that the same thing was true about church history, about preaching, about dogmatic theology.

Thus the theological encyclopaedia was born, the Bible became the object of autonomous academic study, the fetters of the church were shrugged off and theology itself (as aggregate term of the various disciplines) became but one of many disciplines in the modern university setting.

The notion of theology as habitus or personal formation was carried on by continental pietism, initially as a reaction to the medieval scholasticism, but later also as a reaction to

3. The University of Halle, founded in 1694 is frequently referred to as the first modern University. 
the rational and liberal approaches to theology at Enlightenment institutions. This concern for individual formation, faith issues and discontent with a purely rational approach soon drove practitioners of this brand of theology from the modern university to other institutional locations: primarily that of seminaries, and gradually the emphasis changes from individual spiritual formation and practical knowledge/wisdom, to the technical training of ministers. Farley (1983: 43) comments that 'the tasks of the ministry are the ratio studiorum, the rational for the disciplines... According to that model it is necessary for the minister or prospective minister to know certain things. This knowledge is simply knowledge ordered toward and required by the tasks of ministry.' Theology thus also becomes technical knowhow for ministerial tasks.

This is still the situation we find ourselves in today: there are two distinct branches of theological education: one more academically inclined, and the other located in denominationally dominated seminaries. Ironically, nowadays, there is very little difference between the two in terms of appropriating new methodologies, terminology and the like. It seems that the major difference in the emphasis put on faith in the latter: after all, institutions training people for ministry, also have to account for faith issues, while the Enlightenment driven university Faculty of Theology need not necessarily do so. Sufficet so say that it is within a cadre of theology as subscribing to the ideals of the Enlightenment that the academic study of the Bible, both as a school subject (not formative Bible classes) and as an academic subject Biblical Studies, Old Testament, New Testament) can be situated. There have been, of course, some corrections of the pure Enlightenment model, but to a large extent, and because of university structures in Europe which also dominated the scene in South Africa, this Enlightenment model was retained in its basic form in especially the field of the study of the Bible.

I will devote the rest of this paper to indicate how the academic study of the Bible has become irrelevant at universities exactly because it is an academic enterprise of the nature described above. I will conclude with brief observations on how one can approach solutions to this dilemma, and not only follow the American lead here in South Africa and to a large extent ban any form of the study of the Bible from public universities.

\section{Consequences of the academic study of the Bible: Seeds of irrelevancy introduced}

The fact that theology and later on the various theological disciplines like Biblical Studies found a place at the Aufklärung university has had some serious consequences: on the one hand in brought theology and the study of the Bible firmly into the scientific world, and gave it scientific legitimacy, but it also has had such far reaching negative ramifications as to bring about the present crisis of the irrelevance of the academic study of the Bible, which have been felt in other parts of the world in the last 40 odd years, but which is causing concern in South Africa at present.

There are quite a number of reasons for the current problematic situation regarding the study of the Bible, and I will only focus on a few of the more fundamental problems inherent in the way in which the academic study of the Bible has been conducted in the past. Under the first two headings $(3.1 \& 3.2)$ I will be considering problems inherently part of the academic study of the Bible, stemming from the underlying epistemology of the

4. Under the leadership of Wilhelm von Humboldt, who envisioned the University of Berlin to be the first modern research university, FDE Schleiermacher argued, successfully in the end, for the incorporation of theological studies in to the curriculum at Berlin. 
Enlightenment university, and under the third heading I will briefly pay attention to some external factors (although closely related to the above), aggravating our irrelevancy problem.

\subsection{Irrelevancy and the Biblical sciences as 'value-free' or 'neutral'}

One of the effects of the academic study of the Bible and of having it incorporated into a liberal arts setting is that this 'scientific' location of something like Biblical Studies, has had a profound effect on the way in which it has been handled in the past. Some of the most serious objections to the continued existence of Biblical Studies and also much of the current political attack on Biblical Studies as either irrelevant or illegitimate or both, to my mind, stem from the fallacy that the study of the Bible can be neutral, objective and value-free.

Elsewhere ${ }^{5} \mathrm{I}$ have argued that Critical Theory as developed by the Frankfurter Schule and Jürgen Habermas in particular provides one with some unique insights on what has taken place in the development of scientific investigation since Aristotle, and to my mind offers a valid, and very necessary correction to the Enlightenment idea of what scientific knowledge is. As we have indicated, in the Aufklärung university, theology and the study of the Bible found itself firmly entrenched in the Enlightenment idea that scientific investigation ought to be neutral, objective, critical and above all rational: that is, devoid of personal considerations. Habermas objects to this and argues that in this process:

the Aristotelian notion of intersubjective praxis has been subordinated to a kind of techne. He holds that in Aristotelian society, questions about virtue, worth, value and dignity were never divorced from the political praxis. However, Habermas traces the development in the political thought through medieval times through that of Machiavelli and More and later in the 17th century, that of Hobbes, and explains that gradually a more technical approach to politics, with less emphasis on the contribution of ethical and philosophical discussion about virtue and value and what it means to be fully human, came about. A rift between knowledge per se and practical action (which includes ethical considerations) began to appear. 'Theoretical knowledge' now began to mean the construction of explanations which could explain in scientific manner certain phenomena, totally in isolation from considerations of value and so on... The immense successes of the natural sciences in the 17 th and 18 th centuries aided and abetted this perception of the triumph of the 'new learning', and the views of what scientific knowledge entails... Kant of course, also contributed to the discussion and Habermas indeed picked it up. He gave Kant his due credit for overcoming naive realism, but levels some critique against Kant's concept of individual subjectivity and the separation of the critique of knowledge for the critique of rational action (see Habermas 1971:17). His second point of critique against Kant was that Kant chose to work with a specific kind of knowledge, that is, rational scientific knowledge of the day, which was destined to overwhelm every possibility of also taking knowledge where morality, humanity, and values can also play a role, into consideration. This is for Habermas a serious deficiency in the development of perceptions regarding scientific knowledge. Habermas contends that also in the development of the social sciences knowledge was indeed perceived to be in line with the knowledge of the natural sciences, that is, value free. The latter half of the 20th century has indeed proven this assumption that knowledge is value free to be wrong, for 'the supposedly value-free social sciences have all too frequently functioned as servants of powerful nations and ideologies' (Campbell 1992:33). Knowledge is never without

5. 1993. Habermas, Critical Theory and Teaching Biblical texts with integrity. Scriptura S11, 69-87. 
vested interest, is never not historically rooted. It is therefore necessary for Habermas to establish a social science where there is a change in the way in which knowledge about society is formed, so that these reconstructed social sciences should also be able to not only describe society in terms of legitimate rationality, but also to evaluate it, and to offer explanations that will empower the citizens to change their own society and thus serve an emancipatory function... The way to approach this emancipatory kind of knowledge is to realize that the ideals of the Enlightenment was not realized. The thinkers of the Enlightenment were convinced that a rationally constructed society would be a fee and happy one -- a society where the secular autonomy of objective science, a universal and rationally designed system of morality, law and government and finally freedom in the arts, were upheld. Rationality and emancipation were supposed to be linked. However, the idealism of the Enlightenment has never been realized and history has proven exactly the opposite. All suffered as a result but especially the Third World has felt the brunt of this. The rigid application of rationality to life, while it did indeed bring about much greater freedom from natural necessity, it placed increasingly rigid and oppressive restraints on cultural development and especially in societal spheres. Max Weber considered this eventual 'iron cage' the inevitable price to pay for a rationalized social life (Weber 1958:182).

(Botha 1993:74)

For Habermas then, one of the most critical aspects is that no knowledge can function in a vacuum and that the idea of 'value-free' knowledge is a fallacy. This is also true of theological knowledge and reasoning and also true of the scientific study of the Bible. In the past, mainly because science was seen to be rational and neutral, the scientific investigation of the Bible and something like the supposedly neutral historical critical method was also viewed in this light. It was assumed that a 'neutral' Bible science was possible. Habermas however, has pointed out that this is not the case and that all knowledge and scientific endeavours are contextually linked, fraught with ideology and vested interests and can serve as mighty vehicles of oppression ${ }^{6}$. We have in this country also seen this in the ways in which supposedly 'neutral' and 'scientific' and 'objective' readings of Biblical texts were actually employed to further the causes of an apartheid system. The assumption was that theologians were reading the Biblical texts with the best possible scientific methods of the day and that these 'neutral' results co-incidentally supported the political system!

Thus, in the past Biblical Studies as an academic subject in the South African context was presented at universities and schools as if it was a neutral subject, devoid of politics, specific contexts and ideology. While this was the image being projected by many biblical scholars over many years, this was simply not true, but because the western, white male European paradigm was so dominant, its own prejudices, presuppositions and covert ideologies went unarticulated and the whole subject was presented at many institutions as a 'neutral' subject. But just because the (mostly white) presenters of the subject and authors of countless Biblical Studies textbooks experienced their subject as neutral did not make it

6. We have seen the truth of this observation in the field of the study of the Bible in the rise of liberation theology readings of the Bible, of black theology readings of the Bible, of African American readings of the Bible, of feminist readings of the Bible, of gay and lesbian readings of the Bible, of various contextual readings of the Bible, and so on, all of which are a severe critique of earlier (western, white male dominated) readings of the Bible as being illegitimate and totally out of touch with specific interest groups. These allegations are of course to a large extent true, and Biblical Studies in South Africa in particular has suffered a lot from this. It is one of the main reasons of the irrelevancy of the academic study of the Bible. 
so. In essence it has been a western European model which was forced on both white and black South African students alike. It was taken by large numbers of especially black students, not because it was really relevant to them, but because of other considerations under the previous educational dispensation like 'easier' examinations, quick promotions and salary increases. Now, since these exterior motivating factors have been removed, these students do not enroll for this subject anymore. Because it is irrelevant to many students' contexts here in Africa, there is little interest in the subject.

In addition, while the perception was being fostered that Biblical Studies was a neutral discipline, one must also not forget the history of the use and abuse of the Bible during the apartheid years, and the severe criticism of this by many people. In the whole process of being sensitised to the abusive uses of the Bible in South Africa, many began to view the subject Biblical Studies with suspicion, and as a vehicle of sustained oppression. A perception still very much alive in the South African context.

Thus by being presented in the guise of a 'neutral' academic subject, in school and at university, in line with other scientific disciplines, the study of the Bible actually was done a great disservice since behind this image there was the perception that what was being presented was a timeless and scientifically sound neutral subject. And because of this misguided perception, the true nature of the subject as being western and white male dominated escaped many scholars, hence rendering it irrelevant to a South African context and illegitimate in the eyes of many who have felt the brunt of the abuse of this same collection of books.

\subsection{Irrelevancy and interpretative and faith communities: the 'garstige grabe' ever increasing}

Not only can the sustained adherence to the Enlightenment idea of what knowledge is be shown to have had detrimental effects on the relevance of the study of the Bible, but also the way in which Bible scholars have gone about their business, and the utilization of modern interdisciplinary methodologies all have contributed to an ever increasing rift between the world of the Bible and modern day society, thus further contributing to a perception of irrelevancy. There are many of these newer methodologies implemented in the study of the Bible today, like narrative criticism, reception theory and the like. Here I will focus on only one of these as an example: social scientific criticism.

To many, the message and theology of the books of the Bible is very obvious and extremely applicable to today's world. Because of the use of the Bible in the church and various faith communities, and the two paths which developed in theological study: one at university as a science or discipline and the other at seminaries aimed at knowledge, wisdom and formation of the faithful, the way in which the Bible is used, the way in which its authority is articulated (see Deist 1986) differs vastly from pulpit to lectern. Furthermore, because the Bible has a very specific social function in religious circles in modern day society, the assumption amongst virtually all Christian communities is that the Bible must have a message for today, and that it is there to be discovered. The many popular publications on the Bible and interpretations of the Bible by all and sundry, which frequently appear in the form of 'daily readings' 'devotions' or 'dagstukkies' literature, testifies to this. The most popular of these authors, at least in South Africa, have no formal theological training at all, but continue to churn out these popular interpretations of the Bible, assuming without qualm that the Bible has direct significance for today.

Furthermore, many interest groups and also many marginalised groups have also appropriated the Biblical texts and have demanded that in their interpretative circles some 
corrections to traditional Biblical interpretation must be made to make adequate allowance for their specific interests and needs. For instance, the feminist discourse in the US and elsewhere has produced a large number of readings of the Bible to make it more female friendly, less sexist and less patriarchal. The insistence is that the interpretations of the Biblical text must be more ethical, more inclusive, less discriminating. The appropriation of reader response criticism in reading theological texts, has also raised the awareness of the role of the reader in giving texts a specific texture, and this has highlighted the biases, preferences, opinions, ideologies, and stereotypes a specific reader brings to the text. Much more than ever before are we aware of the extremely important role of being conscious of this kind of influences on our reading of the texts and the subsequent effects it has on the interpretation. I think this has been an extremely helpful and important development which Biblical scholars should also consciously participate in. And this has highlighted the need for integrity in reading New Testament texts too and a number of studies on the ethics of interpretation have also appeared in recent years (see eg Patte \& Phillips 1991).

What is true of feminist readings of the text is also true of other readings of the text where specific interpretative communities have demanded that some corrections on more traditional ways of reading the text must be effected to make it more relevant, such as liberation theologies, black theologies, Marxist interpretations of the Bible, gay and lesbian interpretations, womanist theologies and in South Africa a Busadi approach to the Bible, and so on. I am very sympathetic to these endeavours because some of the results of certain readings of the past were indeed oppressive and discriminating and exclusive and dehumanizing to many. I need not go into any detail here.

However, despite many positive aspects in the above, matters are indeed much more complicated and as a Bible scholar I also have some serious reservations about the validity of some of these so-called 'more ethical' interpretations of the text. I have in the past also ventured into the field of contextual hermeneutics and have argued strongly for interpreting Biblical texts with integrity (see Botha 1993). One of the reasons for this reservation on my side is the light shed on ancient societies by the implementation of social scientific criticism in New Testament Studies in recent years. This has also brought the problematic nature of popular interpretations into sharper relief for me. I would thus venture to say here that both the popular expositions of the Bible and interpretation done from a specific interest group viewpoint can be seriously questioned in the light of these newer developments in the study of the Bible.

Historical criticism has indeed shown that world of the past is very dissimilar to our own modern world. Historical criticism has focused on various stages in the development of texts, the various groups, religious groups, and how society was structured in very broad general terms. It was aimed at bringing a historical perspective to Biblical texts, and to place them in specific historical time and this served to help break the stranglehold of the monopoly of ecclesiastical interpretations of the Bible. In time it seems that the historical critical paradigm has become the dominant paradigm of Biblical interpretation in First and Second Testament studies. But, however revolutionary and ground breaking, this paradigm also has serious limitations. Limitations of the kind pointed out by Vorster (1984), but also in terms of not being deep going enough in alienating the reader from the text.

Despite historical critical analyses, and sound exegetical work, over the last 200 years, it is still possible for the majority of Christians to read and interpret the Biblical narrative as a narrative for today. Sure, there are some references to the historical setting of the texts, the probable circumstances and time of writing and so on, but especially when dealing with something as ethereal as the theology or message of texts, interpreters still treat the texts as 
if they are communicating with a modern kind of reader, who shares the same social value systems, the same social consciousness and world view. Nothing can be farther from the truth.

In fact, social scientific criticism has revealed a world so foreign to our own that it is actually mind-boggling. Studies done on the Biblical social values, the economy, values of honour and shame, social stratification and the like of the biblical era have shown that many of the aspects with which we have been very comfortable in terms of reading the Bible, and that many of the truths we find in the Bible, and that many of the guidelines we find in our confident interpretations of the Bible, are actually worlds away from the ancient Mediterranean society of the first century. We live in a modern, post-Aufklärung, technological age, with the value systems, ethics and morality which are generated by it. It does not even resemble the ancient Mediterranean society at all. There are enormous differences between the Western individualistic kind of person and the dyadic personality of the typical first century Mediterranean person (see Pilch 1991, Pilch \& Malina 1993, Elliott 1993, Hanson \& Oakman 1998). And this, taken together with historical distancing between ourselves and the world reflected by the texts should actually make us much more circumspect in our readings/interpretations of these ancient texts and much less confident in utilizing the texts for our own needs whether it is for personal formation or to formulate a new theology or to criticize current, modern social structures or ideologies. In brief, with the additional knowledge shed by social scientific criticism on the people and the world of the Bible, we should now more than ever before realize the enormity of the problem of understanding the ancient texts of the Bible, and applying them to modern needs and situations. Both historical criticism and social scientific criticism actually serve to highlight the foreignness of the texts we are dealing with, and taken really seriously, would render them virtually useless for our modern/post modern needs!

Now back to ethical interpretations of the Bible. First it is important to establish what exactly is meant by this. It seems that various interpretative communities have different agendas, so the exact nature of this ethical accountability in Biblical interpretation will differ quite a lot. Speaking in general terms it seems that ethical accountability refers to the necessity of Biblical interpreters being consciously aware of their own biases and context and opinions when dealing with a text. They are required to know what presuppositions and prior meanings they are bringing to the reading of a text, and indeed there are a growing number of New Testament interpreters paying attention to this, not only from the side of special interest groups and specific interpretative communities, but also from the side of the more 'suspect' interpreters, that is, the white male interpreters (eg see Patte \& Phillips 1991). In addition to this, ethical accountability also implies to many that interpretations should not be exclusive, harmful, discriminatory and sexist in nature. In other words, interpretations are considered to be ethical if they are not harmful to minority, disenfranchised or marginalized groups or individuals. In fact some would go so far and say that interpretations are only ethical if they favour one or other of these groups! The effect is that any reading of the Bible or New Testament must be in line with the above requirements, otherwise it is unacceptable, and can be termed unethical.

But being as it may, and laudable as it may seem, the question still is: is this trend in modern day New Testament scholarship in line with what is being done in the field? To this I would like to answer a resounding ' $N O$ '. The work implied by historical criticism, and the recent ascent of social scientific methodologies with it alienating function should be taken very seriously in this regard. I would like to state categorically that if the world of the text, and the ideology driving the particular text is not foreign to modern day interpreters, then 
something is seriously wrong with the reading of the text. Add to this that ancient texts were not written with modern biases and modern understanding of equality and liberty and individual values, it becomes hard to understand how almost all the New Testament theologies seem so logical, meaningful and readily applicable to modern day society and the church.

I detect two problems in this regard:

- the first problem is that many New Testament interpreters are not yet taking the problems created by modern scholarship really seriously. I have dealt with the alienating effect the text should have, but clearly does not have. Because we are dealing with books sanctioned in the church through many generations, the fact that these texts form part of many people's socialization process, and the fact that so many are extremely familiar with these texts, the assumption is made (also because of historical reasons like the claritas of scripture) that these texts are directly accessible, readily understandable and directly applicable by all to all of today's situations. This is putting it rather bluntly, but even in cases where theologians are aware of these problems, one usually finds some acknowledgement of the fact, but the procedures followed in determining a message, and constructing a theology or message for today, seldom takes the distance seriously. It is assumed that the messages of the various books of the Bible must make sense to modern readers. If it doesn't, it can be discarded, although nobody in a church would admit to it. It is easier to discard large chunks of the Old Testament in this way, (like many of the Old Testament legal texts), but it becomes more problematic in New Testament texts, but it is still being done. At this stage I am not going to condone or reject this practice, but would like to point out that this is seldom questioned.

- The second problem in this regard is the fact that in many cases an unrecognized bias plays an extremely important role. This is the unrecognized bias of being part of a Christian believing community. With this bias comes a large number of presuppositions dealing with nature of the Bible, the inherent worth and message of the Bible, some presuppositions regarding the Bible somehow representing the 'Word of God', the status of Biblical texts and last but not least the assumption that the Bible communicates over time and distance. All of these can seriously be questioned ( see also Deist 1986 in this regard).

In the light of the above, I would like to ask the question about the ethical accountability of readings again. If a reading of text, after taking various historical critical, linguistic, literary and especially social scientific aspects into consideration, gives an indication of an underlying ideology which is extremely foreign to us, or the discovery that the Gospel of John is anti-Jewish, sexist, patriarchal, racist, excluvistic or some such thing, is it necessary to make the reading or the theology of it more ethical? Does this really do justice to the text? Some texts of the Bible are indeed racist (see Leviticus) and sexist (see Paul) and excluvistic (see John \& $1 \mathrm{John}$ ) and uses patriarchal language (see the Psalms), and condone the gross violation of human rights by slavery (Deuteronomy \& Philemon) and all of them reflect the pivotal values, the societal norms, the systems and sensibilities of the past and each of them is the product of a very specific group, at a particular time of their development, with a specific ideology, aimed at a specific audience of the ancient, not modern, society.

Granted, many theologians, especially those serving faith communities, would like the book which to many is a book of faith, to be a book one can be proud of in a modern day society. We would like to book to be ethical, and just, and egalitarian and liberating in the way we perceive these values. This is what feminists and contextual theologies and liberation theologies are demanding of our readings of these texts. However, a comprehensive reading 
of these texts reveals that they are not this at all. These texts are the products of their time and no amount of fiddling with them would make them otherwise. Women were in an inferior position in societies of the time, discrimination on the ground of gender and national origin was in the order of the day. People were not interested or fired up with human rights, in fact, social scientific studies have revealed that they were not even interested in equality, because it was not a social value of importance in that society. We would like it to be, but at the time, it was not. How then can our readings of these texts, if they are responsible, reflect this kind of value? It is just not true to the texts themselves. Elsewhere ${ }^{7}$ I have dealt with the issue of Biblical social values, and have indicated that in most instances they are diametrically opposed to modern (western) social values. How then can we propose to build our own modern day perceptions of good and evil on this? Is not our traditional readings and understanding of the inherent value of the Bible so skewed by ecclesial influence that most scholars refuse to even contemplate these issues? There is also the assumption that may of our current modern social values are the result of the influence of the Bible. I would contest this: many of the social values we have in our westernized society today are there, and were generated by post-Enlightenment philosophy, post-industrial individualism, and certain compatible interpretations of the Bible, and not by the Bible itself! A good example of this is individual human rights. This is not a concept compatible with any of the pivotal values we find in the ancient Mediterranean. It has other roots, but by hook or by crook many believe it is a biblical value too!

Would it be inconceivable that we could say that the book we know as 1 John was produced by a group (faction or sect) who were only interested in their own survival as a group, and did not care if they were increasingly being isolated form both their Jewish roots and the Christian mainstream traditions? Their infighting was severe and their only interest was in guarding their group identity by laying claims to special knowledge, and emphasizing love for one another in the group as sign of commitment. Would it be inconceivable to say that 1 John actually has very little to offer modern believers because their circumstances, social values and identity seeking techniques reflected in the book are so totally out of line with what we are faced with today in society that is does not really have a theology from which we can benefit? And this implies that the message we can read from the book is that (taken our modern value systems today), the way in which they went about their business is a big 'no no' for us today?

In some ways I think this kind of approach would liberate the Biblical texts to be what they really are: documents of faith from an ancient world, which can or cannot be significant for us today. This would also liberate the interpretation of these texts from the necessity of being ethical in modernist or even post-modernist terms. It is not necessary then to change the language of the New Testament and Psalms to be more inclusive. The language of the Bible was not inclusive: it was male dominated. If we today want to force the view that language should be inclusive on the Bible, it is to bring a very modern view about the way in which societies are supposed to function to bear on an ancient collection of texts which are not participating in the same discourse at all. To pretend that the Gospel of John has universal tendencies and that it is not propagating Jesus as the only true way to the Father, is to do the text and theology of John an injustice. I totally agree that in the light of our modern value system and all that is implied by it that the way in which we structure our society and use our language and construct a bill of human rights and deal with people from

7. Biblical social values and African social values today, in: Du Toit CW (ed) 1997. Images of Jesus, 162-184. Pretoria: Unisa. 
outside our group and treat women and the poor and disenfranchised, we should strive for ethical accountability in our religious discourse too, but whether that also includes forcing Biblical texts to reflect a value system totally foreign to them, I am not too sure. In any case, making believe that the Bible is a document of nondiscrimination and modern egalitarianism and democracy and to have it reflect values not yet in existence in the ancient world, is to my mind as unethical as the worst of Biblical interpretations.

Our problem is not really the Bible, but our expectations of it. In the past our expectations were that we could count on it to actually be timelessly relevant to us. Because we expected it of the Bible, others, like liberation theologians and feminist theologians have taken us to task on it. They asked us to deliver the goods, based on our own presuppositions and pointed out quite correctly that these interpretations were not ethical and accountable to a modern set of values. In this they were not incorrect! However, the way out of the dilemma is not to try and force New Testament interpretations to be more ethical or accountable in a modern sense. The way out of this is to correctly use the best possible tools at our disposal and try to arrive (as best as possible and with total regard for our own ideological positions and presuppositions) at a reading that would do justice to the texts of antiquity we are dealing with. The problem of ethics does not so much lie in the way in which we read the Bible, but in the way in which we construct and conduct the broader religious discourse in which these kind of interpretations function. To be ethically accountable, this broader discourse must also be ethically accountable: it is no use for the individual readings to be ethically accountable, if the broader discourse is not. A good example this kind of fallacy is the use and abuse of the Bible in an apartheid discourse. In addition, we would have to reconsider the position of the Bible and this implies that we take a new look at the various confessions and also at the position and status of the Bible as a document of faith. This is no simple undertaking, and many aspects are involved which in this present time seem to me to be insurmountable obstacles to this. Suffice it to say, that the dialogue regarding ethical accountability in interpreting Biblical texts, and the discussion of the validity of 'popular and timeless' reading of the texts by ordinary believers needs to be furthered.

To conclude this section: Viewed from a certain perspective, the Bible can be considered actually irrelevant for today: both the historical critical and social scientific methods have made this abundantly clear. We have also questioned popular interpretations, pious interpretation, and sectional interpretations alike, and if approached from this angle (a purely academic, scientific angle), the Bible indeed is irrelevant for both ordinary Christians and also for specific interest groups, even if they pretend it is otherwise! The continued academic study of the Bible, if taken really seriously, moves us further along the path of irrelevancy.

\subsection{External/additional factors enhancing irrelevancy: 'usefulness', politics and a secular state}

Under the above headings I have dealt with problems inherent to the academic study of the Bible which renders it rather irrelevant, but there are also quite a number of external factors which enhance the irrelevancy of the academic study of the Bible specifically in the South African context which are closely linked to what I have argued above. I will focus only briefly on some aspects here and will argue that what lies behind this trend in higher education world wide is the 'fragmentation of knowledge' and 'the rise of speciality fields' which in the modern university have slowly been replacing disciplines (Farley 1988).

- The first that must be taken into account is the fact that in this country with its immense social upheavals of the last few years, we now have a new constitution, and that contrary to the past 
situation we now function in a secular religiously and culturally pluralistic state. For many 'secular' spells 'non- religious', but that is actually not the necessary conclusion. The new constitution indeed makes allowance for constitutionally entrenched freedom for all religions, but what has changed is the monopoly of protection of only a certain segment of the religious spectrum. For many this spells the necessary demise of the study of religious texts at universities. It is further fostered by the idea that secular states must of necessity have secularised institutions of higher learning and secular universities means for many in this regard no religious studies of any kind. The idea is that the study of religious texts like the Bible is the primary task of denominations and that for the Bible the place where this should be taking place is the seminaries of the various denominations.

These ideas are of course not new or uniquely South African: the process of the secularization of certain universities, especially public universities has been going on in the USA since the 1870's (see Marsden \& Longfield 1992; Marsden 1994), and has also been done in Great Britain (see Bebbington 1994), Canada (Rawlyk 1994), Australia and New Zealand. So the developments we have in South Africa are really nothing new, and despite claims to uniqueness in the report of the National Commission of Higher Education of 1996, and the proposed National Qualifications Framework's, are following the lead of many other countries, which to my mind the only exception being that the rationale of the NQF, SAQA and so on is more clearly articulated than in other countries and that the focus on qualification driven education renders the distinctions between Universities and Technikons virtually obsolete. However, the way in which the role of the study of something so specific as the study of the Bible is being dealt with is exactly in line with what happened elsewhere in the world (see Marden \& Longfield 1992).

- A second prevalent development which tends to render religious studies and the study of the Bible at universities irrelevant is a new spirit of utilitarianism. In other words, any discipline presented must have a very specific usefulness in society. I will not belabour the point by arguing for or against it. Suffice it to say that this has become part and parcel of tertiary education in South Africa, and is firmly entrenched and strengthened by the fact that an outcomes based education system is being followed. In the SAQA regulations issued on 28 March 1998 under the SAQA Act, in paragraph 7(3) certain critical outcomes for higher education qualifications are spelled out and include statements like

...contributing to the full personal development of each learner and the social and economic development of society at large... by making an individual aware of the importance of... exploring education and career opportunities; and developing entrepreneurial opportunities.

Based on these and many other similar statements, the argument is that the study of the Bible is not useful, equips people with very few practical skills, does not contribute much to economic growth in the country and is not useful for people in obtaining employment. Over the last few years there has been a growing sense that 'the ivory tower' or the 'theoretical reflection' of traditional liberal arts institutions and university academia should be more relevant and should be more practical, abhorrent as this may sound to those who subscribe to the bigger ideals of the Enlightenment university! I would even venture to say that the (false) dichotomy between universities as more theoretical and technikons as more practical institutions in South Africa which was so dominant in the past is now being overcome not by technikons approaching the university model, but that the university model is now more closely resembling the technikon 'model', and it is not because technikons have 
become more university-like that they are now being allowed to confer degrees, but that essentially the realization has dawned that technikons and universities fulfill the same practical functions and this tends to blur the sharp edges between the two. More and more universities are venturing onto other terrains, previously reserved for institutions of 'lower rank' like colleges and technical colleges by presenting a plethora of short courses, certificate and diploma courses. Again, even this enterprise is demand driven, driven by economic considerations and pragmatics. Even the rhetoric within higher education institutions reflects these changes, and academic departments become 'cost-units', we talk of our 'core-business', 'students' have become 'learners', or even worse, clients. Before new courses can be introduced the opinions of 'stake-holders' must be tested and 'marketing' is the name of the game.

The question that needs to be answered here is of course, where does this come from? This is so far removed form the ideals of what universities used to stand for. Ed Farley in his 1988 book The Fragility of Knowledge argues that knowledge is the 'university's business, its remuneration and responsibility'. However, this knowledge is fragile, and also corruptible. He further argues that the Enlightenment ideal of knowledge was that knowledge was historical, culturally determined and thus

carried by words and writings that are laden with ambiguity, interpretation and errancy. The words that knowledge employs are never mere obedient emissaries of reality. The result is that human knowledge is never an absolutely settled accomplishment. As historical it is always a candidate for further inquiry, renewed clarification, new discursive forms. In other words, the accomplishment of knowledge always occurs as criticism. The Enlightenment ideal is, therefore, the ideal of critically accomplished knowledge. And this is why the Enlightenment contrasted itself to the dogmatic temper, to knowledge by tutelage, to mere appeals to the authoritative past. Under the ruth less instrument of criticism (the Enlightenment called it reason), there were no exceptions. No a single one of the cognitive successes of the past could be taken for granted...

(Farley 1988:4-5)

He continues to show that through the years various correctives to this ideal have been brought from various sides, but without repudiating the critical principle or the empirical basis. For instance, a correction came from the side of Romanticism, whose proponents argued strongly against the 'abstracting' tendency of the empirically focused methodologies of the Enlightenment. Knowledge is more than abstractions, because reality is more than the abstractions (Farley 1988:6). Another corrective came, interestingly enough, from the side of theologians, who Farley indicates did resist the Enlightenment and tried to keep their own doctrinal and moral tradition and its Scriptures beyond assessment on the grounds that they are the standards, the touchstones of criticism (Farley 1988:7). The essence of the correction underlying the opposition from the churches was the Enlightenment view that tradition and reason were mutually exclusive. The theological corrective thus was that the view that tradition cannot be a bearer of truth, is purely arbitrary, and not acceptable.

'The third corrective of the Enlightenment is a radicalizing of criticism' (Farley 1988:8), which means that there must be a realization that even cognitive endeavours are in the service of power structures: there is no pure reason at all. This basically also the viewpoint of Habermas discussed above. Farley (1988:11) says that we have inherited both the Enlightenment tradition about the nature of knowledge and the various correctives, but that these correctives have had 'very little power to exercise their corrective function', and consequently we have moved into a paradigm, basically inherited from Bacon and Newton, 
which has become the dominant paradigm, because with its precision and technological implications have virtually created the modern world.

I am talking about a paradigm, a model of knowledge that works better for sciences than others, but has expanded to most of the speciality fields constituting the social sciences and humanistic scholarship. According to this model understanding occurs as the result of concentrating research upon a very specific aspect of something' (Farley 1988:11).

In this there is very little left of the various correctives, and Farley contends that the correctives exist only as marginal in modern science. This, according to Farley $(1988: 15)$ has produced a contemporary scholarship that is specialized to the point of triviality, preoccupied with technologies of method and with reworking already surfeited subjects with ever more ingenious procedures... In such a situation, knowledge, always fragile, is distorted.

This distortion of knowledge and the lack of deep going criticism, results for Farley (1988:35) in the rise of 'Speciality Fields', which he contends has slowly but surely begun to replace disciplines as 'the primary agents of the university's endeavour'. For him a speciality field is a social entity in which much of the professional scholars work, and spend their time and publish: scholars are no longer active in a discipline but in a speciality field and this Farley laments as reductionist, abstractionist, narrowing and calls it 'narrowed empiricism' (1988:40-42).

This has come about because of the incredible engineering and technological successes which have shaped the modern world.

'As a result the quantitative sciences now set the paradigm for study and research, as well for what reality is and how it is known. Since these sciences build on procedures that focus on specific measurable entities whose internal structure and external behaviour can be studies by introducing environmental variables, the result is the detailed knowledge of physical and genetic 'building blocks' and processes of the universe. Such knowledge makes possible an astonishing application of science to problems of health, disease, injury, weaponry, transportation, communication' (Farley 1988:41)

From here it is a but a small step to view all the disciplines or speciality fields in this light, and measure them against each other in terms of this 'success' which for Farley (1988:43) severely compromises universities, and which leads to universities pursuing what he calls 'impoverished knowledge' as a result of this 'narrowed empiricism' which tends to dominate the university scene all over the world. In the process a number of crucial aspects are suppressed. Farley says that the biggest problem in this regard is "not so much of the quality of what this empiricism yields in social and humanistic sciences as because of what it excludes from inquiry' (1988:43). For Farley this is what lies at the root of many of the problems of the human and social sciences in the modern university: all are forced to adapt to the dominant paradigm, and are expected to yield spectacular results similar to those of the engineering and physical sciences. Many humanistic sciences succeed in this, because part of their disciplines lends itself to this kind of endeavour, like the management sciences, where close scrutiny of an ever changing object of research, be it human or organization, continued to yield fresh and new advances. But sciences, like Bible sciences, which build on a more static and fixed object like a corpus of religious books or a specific era, if it plays the prescribed knowledge-game of ever increasing scrutiny of detail, soon finds itself trivialising itself. Not because it is trivial, but because it is playing in the wrong league, so to speak.

Unfortunately, this dominance of 'narrowed empiricism' and the rise of 'speciality fields' and the dominance of practical results orientated knowledge according to the physical 
sciences model have had a disastrous effect on higher education, the results of which we are currently seeing in the NQF and the continued irrelevancy of speciality fields like Bible studies. Link this with a mistaken perception of what a secular society entails, and it is clear that religious studies and the academic study of the Bible have no option but to vanish from the academic scene.

\section{The relevancy of the academic study of the Bible in South Africa today}

I have painted a rather gloomy picture, and the situation is indeed grave, there is no doubt about that. The only question that needs to be answered now is: can the situation be remedied at all? Is the academic study of the Bible really as irrelevant as I have indicated? Can the academic study of the Bible and the continued existence of an academic (nondenominationally linked) theology be relevant in the light of the above? Certainly, the arguments against this are extremely strong, both viewed from within the discipline and viewed from without. However, I believe that there are some measures that can be taken and certain perceptions that need to be altered which could perhaps make the continued academic study of the Bible and also theology at universities more acceptable. No, not merely more acceptable, even desirable.

I am just going to make a few observations and give a few pointers because at this stage it is extremely difficult at this stage to anticipate what is going to happen in the near future in the academic world, what the outcome will be regarding teaching of religion in schools and in higher education (the significance of the findings of a panel appointed by the Minister of Education taking a new look at religious education are by no means clear yet), how SAQA will react to Biblical Studies syllabi which are on the way to them and even which direction individual universities, and even Unisa, will take in this regard. Suffice it to say that at Unisa a newly designed syllabus for Biblical Studies and Biblical Archaeology has been submitted to the Arts Faculty and once approved by Senate this will be submitted to SAQA for approval and possible accreditation.

However, I feel that some of the observations made above could point to some shifts that can be made which would at least address some of the irrelevancy problems.

The first observation I would like to make is that in terms of epistemology we should as Old and New Testament scholars take the critique of Habermas and also of Farley much more seriously, and introduce a frank discussion of the epistemology or epistemologies current in the guild of Biblical scholars. Our knowledge and our way of approaching the Bible is indeed flawed in many respects and the corrections proposed over the years of the Enlightenment model have not really been implemented or taken effect at all. Only if we become aware of how knowledge can and has been distorted, narrowed and compromised, can we begin to address some of these problems. This will inevitably mean that issue of contextualizaion, contextual hermeneutics and contextual exegesis will begin to have a greater emphasis. This will go a long way in addressing some of the irrelevancy problems we currently face. It will also necessitate that we rethink the role of University over and against that of Technikons. Unless we redeem knowledge to be more than what it has become, we will continuously be under threat of closure and be compelled to engage only in a practical results oriented endeavour. Again, it is not wrong to have this, but the problem does not so much lie with what is achieved, but by what is lost and not said or explored. The exploration of the 'unsaid' is the unique terrain of the university, and we re under threat of losing this facet.

In addition, the fact that the current situation in academia and the epistemological point of departure in many sciences, or rather speciality fields boils down to narrowed empiricism 
must be pointed out and a new discourse on what we are doing in universities, as opposed to what we ought to do, should be introduced. If we do not protest and protest loudly and vehemently, the dominant paradigm with its 'usefulness' ethos will prevail. Unless we begin to participate in the 'usefulness' debate and point out that religion has indeed a very specific positive social function (see Davis 1992) and that in a broader sense 'useful' could and should be defined in other terms to that of the engineering and physical sciences. We should begin to move beyond modernity and towards a post-modern paradigm of understanding (see Davis 1994: 153-157). The fact that religions plays a major role in society and that the Christian segment of society covertly exercises a huge influence and contributes much to the religious discourse in society should be spelled out much more clearly. For instance, the whole TRC process with its emphasis on truth and reconciliation and forgiveness should be placed into proper perspective and the huge influence of Christian religious tradition on the formation and function of this also pointed out. We can indeed agree with Davis (1994:46) that

the traditional social form of religion, which presupposed that religion was a structuring principle of society, is now obsolete. The social end of religion is in that sense a fact. We live irretrievably in a secular society. Once it has been grasped that the social order is the result of human agency and not a pattern imposed by some exterior or transcendent principle, there can be no going back from that insight.

However, the fact that religion no longer is the 'structuring principle' in society is in fact very positive, and by no means renders religion obsolete: that would be the wrong conclusion and a fallacy which many in the field of higher education today in South Africa seems to subscribe to. The fact that religion lost this structuring function means indeed that the role of religion can and should be reassessed. Davis (1994:46) observes that

religion, while no longer a structural principle, can still be a social factor. It can relate to society as a critical principle. Its exclusion from the institutional structure has released it as a permanent critique.

And it is exactly here where Biblical scholars can play a major role, in line with the critical ideals of the Enlightenment: our participation in the religious discourse in the South African context must always be critical, always transformative and always relevant. The new social role of religion in a pluralistic South Africa, must be explored and once again, the unique contributions to this by the study of the Bible must be explored in full and also more than ever publicly pointed out.

In the third place, there is one last observation I would like to make. In the whole discussion of the legitimacy of the academic study of the Bible, the recent rhetoric has been that to study the Bible, the book of Christianity, and to employ academics at a publicly funded university is indefensible and that at most 'religious studies' where multi-faith studies are explored have a right to existence. In order to answer this objection, I would like to turn back to Schleiermacher, who was so influential in getting Theology established at the modern university as a Faculty, along with those of Law and Medicine which are also not 'pure' sciences. Bassett (1998:11) indicates that Schleiermacher said that theology itself is a 'positive science' although its basis of knowledge is revelation. Bassett further explains that it is for Schleiermacher a positive science because

'we can identify objectively two related factors requiring theological study. First, every society testifies of itself that it has religious needs; and most societies, including Prussian society, have established empirically defined institutions -- in Prussia's case churches -- to 
met those needs... Secondly, we can objectively identify a universally accessible, rational explicable, experimentally observable, culturally determinate from of personal and societal existence through which these needs are met. It is called religion. Religion creates communities. Those communities have their own distinctive 'constitutions', as it were (in Prussia's case, the Bible)... distinctive modes of believing... specific historic path, again accessible in documents... and empirically verifiable unique patterns of living... So, said Schleiermacher, what is eligible for study in the university is not 'religion in general', but the specific, empirically accessible religion of Prussia. Further, society at large has customarily expected that the religious communities will have leadership which will utilize the body's accumulated knowledge in helping the community... In short, the study of theology (understood as having biblical, dogmatic, historical and practical dimensions) serves to prepare leadership for the church, which is fundamental part of the whole state. therefore it belongs in the university curriculum.

Perhaps we can take some pointers from Schleiermacher in this regard. South African society is a religious society, with an overwhelming majority of Christians, and thus can expect of their public institutions to reflect this fact also in their curriculum. Perhaps Schleiermacher was right in remarking that specific societies do not require 'religion in general' but specific religions, appropriate to that location, be it Prussia or Africa. The historical and geographical location of universities in South Africa seem to be overlooked in the current developments in higher education, or rather, only certain contextual matters, mostly pertaining to economics, demographics and an apartheid legacy seems to have been taken into account. Other contextual facets, which have enormous ramifications for disciplines (eg as history and also theology) such a the role of tradition, the specifically Christian heritage, and the religious needs of people in South Africa are not taken into account at all. Perhaps in future a more comprehensive look at what a contextual model of education specifically in South Africa entails, is necessary. This would not only make the syllabi and the 'critical outcomes' more contextual and South African, but it will also introduce into the larger discourse issues like the specific religious needs of South African society, in which the academic study of the Bible is more relevant.

\section{Conclusion}

The whole issue of the relevancy or the irrelevancy of the academic study of the Bible is very contentious at present, and the debate is far from over, but unless those of us who (still) teach and study the Bible at universities pay attention to our own complicity in the distortion of knowledge and its ramifications, and really shed the fetters of the past in our own discipline, the academic study of the Bible will continue its downward spiral to vanish with out a trace from the face of the modern university. A rehabilitation of what knowledge is for us as Biblical scholars and a much more contextual approach seem to be some of the brakes we can begin to put on this slide into oblivion, and to begin to reverse the process. Perhaps then the academic study of the Bible can begin to be relevant again both to academic and faith communities alike. 


\section{BIBLIOGRAPHY}

Arens, E (hrsg) 1989. Habermas und die Theologie: Beitrage zur theologischen Rezeption,

Diskussion und kritik der Theorie kommunikativen Handelns. Düsseldorf: Patmos.

Bassett, PM 1998. 'I Think, therefore I may sin': The ironies of teaching theologically.

Unpublished paper read at Spring lecture series at the Institute for Ecumenical and

Cultrual Research, Collegeville, MN, USA.

Benhabib, S 1986. Critique, Norm and Utopia: A Study of the foundations of Critical Theory. New York: Columbia University.

Botha, JE 1991. Contextualization: Locating threads in the labyrinth. Scriptura S9, 29-46. 1993. Habermas, Critical Theory, and Teaching Biblical Texts with integrity. Scriptura S11, 69-87.

1997a. Bibilical social values and African social values today, in: Du Toit CW (ed) 1997. Images of Jesus, 162-184. Pretoria: Unisa.

1997b. Style in the New Testament: The need for serious reconsideration, in Porter SE \& Evans CA (eds) 1997. New Testament Text and Language. Sheffield: Sheffield Academic. (A Sheffield Reader)

Campbell, MM 1992. Critical Theory and Liberation Theology: A comparison of the works of Jürgen Habermas and Gustavo Gutierrez. Ann Arbor: UMI.

Davis, C 1994. Religion and the Making of Society: Essays in Social Theology. Cambridge: Cambridge University Press.

Farley E 1983. Theologia: the Fragmentation and Unity of Theological Education. Philadelphia: Fortress.

Farley E 1988. The Fragility of Knowledge: Theological Education in the Church and University. Philadelphia: Fortress.

Gilkey, L 1981. Society and the sacred. New York: Crossroad.

Habermas, J 1971. Knowledge and human interests. Tr by J Shapiro. Boston: Beacon. 1974. On social identity. Telos 19, 91-103.

1977. Discussion, in: Dallmayer, FR \& McCarthy TA (eds). 1977. Understanding social inquiry, 66-72. Notre Dame: University of Notre Dame.

1979. History and evolution. Telos 39, 31-32.

1984. The Theory of Communicative Action. Tr by T McCarthy, vol 1. Boston: Beacon.

-- [1970] 1986a. On systematically distorted communication, in: Klemm, DE (ed) 1986: 209-220.

[1970] 1986b. Towards a Theory of Communicative Competence, in: Klemm, DE (ed) 1986: 221-235.

Beacon.

Hanson, KC \& Oakman D 1998. Palestine in the time of Jesus. Minneapolis: Fortress.

Holmberg, B 1990. Sociology and the New Testament: An appraisal. Minneapolis: Fortress.

Kosmin BA \& Lachman, S 1993. One Nation Under God: Religion in Contemporary American Society. New York: Crown Trade Paperbacks.

Klemm, DE (ed) 1986. Hermeneutical inquiry. Vol II: The Interpretation of existence. Atlanta: Scholars. (American Academy Studies in Religion \# 44) 
Lakeland, P 1990. Theology and Critical Theory: The discourse of the church. Nashville: Abingdon.

Lategan, BC 1991. The challenge of contextuality. Scriptura S9, 1-6.

McCann, DP 1981. Habermas and the Theologians. Religious Studies Review 7, 14-21.

McCarthy, T 1979. The Critical Theory of Jürgen Habermas. Cambridge, Mass: MIT.

McInery, R (ed) 1994. Modernity and Rligion. Notre Dame: University of Notre Dame.

Malina, BJ 1982. The social science and biblical interpretation. Interpretation 37, 229-242.

------ 1986. Christian origins and cultural anthropology: Practical models for biblical interpretation. Atlanta: John Knox.

- 1988. Calling Jesus names: The social value of labels in Matthew. Sonoma: Polebridge.

Marsden, GM \& Longfield, BJ (eds) 1992. The Secularization of the Academy. Oxford: Oxford University.

Marsden, GM 1994. The Soul of the American University: From Protestant Establishment to Established Nonbelief. Oxford:Oxford University Press.

Miller, AO (ed) 1977. A Christian declaration on human rights. Grand rapids: Eerdmans.

Mosala, IJ 1989. Biblical Hermeneutics and Black Theology in South Africa. Grand Rapids: Eerdmans.

Neyrey, JH (ed) 1991. The social world of Luke-Acts: Models for Interpretation. Peabody, Mass: Hendrickson.

Osiek, C 1992. What are they saying about the social setting of the New Testament. Mahwah, NJ: Paulist.

Patte, D \& Phillips, G 1991. A Fundamental condition for ethical accountability in the teaching of the Bible by white male exegetes. Scriptura S9, 7-28.

Pilch, JJ 1991. Introducing the cultural context of the New Testament. New York: Paulist. (Hear the Word vol 2.)

Pilch, JJ \& Malina, BJ 1993. Biblical social values and their meaning: A Handbook. Peabody: Hendrickson.

Polanyi, M et al 1958. Apartheid and the World's Universities: Report on a meeting held in London, November 1957. Manchester: Committe on Science and Freedom

Poythress, VS 1988. Science and hermeneutics: Implications of scientific method for biblical interpretation. Grand Rapids: Zondervan. (Academic books, Foundations of Contemporary Interpretation Series, \#6)

Smart, N (ed) 1962. Historical Selections in the Philosophy of Religion. London: SCM

Wheeler BG \& Farley E (eds) 1991 Shifting boundaries: Contextual Approaches to the structure of Theological Education. Louisville: John Knox. 